\title{
FUNGSI MAHKAMAH KONSTITUSI DALAM SISTEM PEMILIHAN UMUM DALAM RANGKA PENEGAKKAN NEGARA HUKUM DAN DEMOKRASI
}

\author{
Adhitya Widya Kartika ${ }^{1}$ \\ ${ }^{1}$ Universitas Pebangunan Nasional Veteran Jawa Timur \\ Jalan Raya Rungkut Madya, Gunung Anyar, Surabaya, Indonesia \\ E-mail adhityawidyakartika@ymail.com
}

\begin{abstract}
Abstrak
Urgensinya Pemilu adalah pentingnya untuk penjaminan hak rakyat yang tercantum dalam konstitusi dibutuhkan MKRI sebagai checks and balances. Penelitian yuridis normatif dengan pendekatan peraturan perundang-undangan dan doktrin hukum. Hasil Penelitiannya MKRI memiliki peran mewujudkan demokrasi berkeadilan harena memiliki kewenangan pengujian yang fungsinya itu berkaitan dengan prinsip ckeks and balances. Kesimpulan Peran MKRI penting tidak hanya hal perselisihan kuantitatif tetapi juga kualitatif. Hak-hak rakyat yang merupakan kedaulatan rakyat yang dalamnya terdapat prinsip demokrasi akhirnya tergantung pada hakim MKRI dalam hal penanganan upaya yang diajukan warga negara sesuai kewenangannya. Fungsi MKRI dalam sistem pemilu dalam rangka penegakkan demokrasi dan juga negara hukum dapat dilihat dalam proses penanganan sengketa PHPU oleh MKRI. Hakim MKRI yang profesional sebagai the Guardian of Constitution menjaga hak rakyat agar terwujud demokrasi yang berkeadilan. Pertama, sebagai the guardian of constitution dalam system demokrasi di Indonesia dengan menangani PHPU sebagaimana mestinya melindungi hak warga negara yang merupakan salah satu HAM. Kedua, penafsir tunggal konstitusi ketika melakukan penafsiran pada konstitusi untuk PHPU dan hanya MKRI saja yang memiliki kewenangan untuk itu. Ketiga, peran putusan MKRI dalam penegakkan bersifat final and binding terhadap PHPU oleh karena harus dilaksanakan. Hal ini juga secara tidak langsung MKRI melaksanakan fungsinya sebagai pelindung demokrasi.
\end{abstract}

Kata Kunci:MKRI; Hak Konstitusional; Pemilu; Sengketa; Demokrasi.

\section{PENDAHULUAN}

\section{Latar Belakang}

Negara cerminan kedaulatan karena kedaulatan merupakan salah satu unsur dari negara. Pasal 1 ayat (2) Undang-Undang Dasar Negara Republik Indonesia Tahun 1945 (UUDNRI Tahun 1945) setelah Amandemen Ketiga mengatur kedaulatan berada di tangan rakyat dan dilaksanakan menurut Undang-Undang Dasar (UUD). Pasal 1 ayat (2) UUDNRI Tahun 1945 menunjukkan adanya peran rakyat dalam suatu pemerintahan Republik Indonesia. Peran rakyat yang dituliskan dalam norma konstitusi menunjukkan adanya partisipasi masyarakat dalam pemerintahan negara Indonesia yang merupakan cerminan demokrasi dibatasi dengan konstitusi (UUDNRI Tahun 1945). Hal ini merupakan ciri adanya unsur demokrasi dalam pemerintahan yang merupakan salah satu Prinsip demokrasi yang dituangkan dalam bentuk norma dalam konstitusi, artinya adanya negara hukum yang memuat demoktrasi maka dapat dikatakan terdapat negara hukum yang demokrasi. Hal ini tentunya tidak hanya sebatas norma saja tetapi juga bagaimana norma tadi dilaksanakan karena tujuan dari norma tadi dapat terwujud atau tidak dapat dilihat atau dapat dibuktikan pada saat norma tadi diberlakukan dan dilaksanakan apakah sesuai dengan maksud ketika norma tadi dibentuk. Selain itu, Pemilu sering diidentikkan dengan sebuah negara yang memiliki sistem demokrasi karena dengan melalui Pemilulah ada peran serta masyarakat untuk terlibat dalam proses pemerintahan. Pemilu ini merupakan salah satu cara dalam sebuah sistem demokrasi. Indonesia dengan kedaulatan rakyat yang didasari pada konstitusi salah satu perwujudannya dengan adanya Pemilu. Pemilu dilakukan untuk memilih wakil rakyatnya dalam pemerintahan. Hal ini berlaku juga dalam pemilihan Presiden dan Wakil Presiden dengan Pemilu. Pasal 6A UUDNRI Tahun 1945 menjelaskan pemilihan Presiden dan Wakil Presiden dengan cara Pemilu. Sedangkan Pemilu merupakan himpunan dari hak rakyat pemilih yang diatur dalam UUDNRI Tahun 1945. Oleh karena itu, Pemilu adalah hal yang penting terkait dengan hak warga negara.

Hak warga negara diatur dalam konstitusi. Konstitusi mengatur hubungan antara warga negara 
dengan negara. Pada konstitusi terdapat pasal terkait hak-hak warga negara (Pasal 28A sampai dengan 28J UUDNRI Tahun 1945), artinya konstitusi mengandung norma perlindungan terhadap warga negara. Agar tujuan pada norma terpenuhi maka perlu pelaksanaan bahkan penegakkan. Konsep Hak Asasi Manusia (HAM) di Indonesia yang diatur dalam UUDNRI Tahun 1945 dijiwai dari konsep HAM Kontemporer yang memiliki ciri subjeknya adalah individu (laki-laki dan perempuan); diatur dalam undang-undang nasional dan konvensi/perjanjian internasional; tidak saja hak individu juga sebagai kepatutan moral dan kepentingan umum; bebas untuk dan bebas dari, bidang sipil, politik, ekonomi, sosial, dan budaya; negara turun tangan; paham prularisme dan particular) (Saldi Isra, 2014). Perlindungan terhadap HAM juga diatur dalam DUHAM yang mengatur tentang keikutsertaan dalam pemerintahan di negaranya, kesempatan yng sama diangkat jabatan pemerintahan, dan kemauan rakyat menjadi dasar kekuasaan pemerintah (Pasal 21 ayat (1), ayat (2), ayat (3) Deklarasi Universal Hak Asasi Manusia (DUHAM)). Begitu pula dalam konstitusi pun ada dalam Pasal 27 ayat (1) UUDNRI Tahun 1945 bahwa warga negara terdapat kedudukan yang sama dalam hukum dan pemerintahan. Hal ini diperkuat Pasal 28 D ayat (3) UUDNRI Tahun 1945 adanya kesempatan sama dalam pemerintahan. Serta dituangkan dalam produk hukum turunannya yaitu Pasal 43 UndangUndang Nomor 39 Tahun 1999 tentang HAM adanya hak dipilih dan memilih pada suatu Pemilihan Umum (Pemilu). Pengaturan berkenaan dengan Hak Warga Negara pada Pemilu merupakan wujud keikitsertaan masyaraat/rakyat dalam proses pemerintahan. Hal ini merupakan bagian dari prinsip demokrasi. Konsep demokrasi memberikan landasan dan mekanisme kekuasaan berdasarkan prinsip persamaan dan kesederajatan manusia serta menempatkan manusia sebagai pemilik kedaulatan disebut prinsip kedaulatan rakyat (Jimly Asshiddiqie, 2015). Produk hukum tersebut merupakan cerminan prinsip negara hukum karena yang akan dilakukan oleh pemerintah yaitu terkait pelaksanaan demokrasi (Pemilu) diatur dalam konstitusi khususnya terkait dengan Hak Warga Negara sebagai wujud peran serta warga negara/ rakyat/ masyarakat dalam proses pemerintahan. Artinya, jika dipandang dari aspek pengaturan merupakan pencerminan pelaksanaan prinsip negara hukum dan demokrasi. Jelaslah bahwa hak warga negara dalam Pemilu diatur dalam konstitusi dan diperkuat dengan aturan turunannya berikut ketika sudah diatur dalam bentuk norma konstitusi tentunya upaya perwujudan tujuan konstitusi berlanjut proses pelaksanaan dan sampai tahap penegakan. Pelaksanaan ketentuan tersebut salah satunya dilaksanakan Pemilu mengikutsertakan masyarakat dan dengan pemenuhan hak-hak diatur hukum.

Pada Tahun 2019, Pemilu diadakan serentak. Walaupun tafsir terhadap definisi pemilu serentak mengalami bias karena tafsir diserahkan ke pembuat undang-undang (Moch. Nurhasim, 2019). Pemilu serentak biasa disebut pemilu konkuren dilaksanakan memilih lebih dari satu lembaga demokratis dalam waktu bersamaan, diantaranya eksekutif dan legislatif pada tingkat nasional, regional, maupun lokal (Apolonaris Gai dan Frans Bapa Tokan, 2020). Pemilu 2019 yang dilakukan secara serentak merupakan kosekuensi yuridis putusan MKRI No. 14/PUUX1/2013 kemudian Undang-undang Nomor 7 Tahun 2017 tentang Pemilihan Umum (Kornelius Benuf, 2019). Pemilihan serentak pada tahun 2019 di Indonesia yaitu pemilihan terhadap wakil rakyat dari Presiden, Wakil Presiden, DPR, DPD dan DPRD dilakukan dalam satu waktu. Hal ini memerlukan usaha ekstra dalam penyelenggaraannya yaitu Komisi Pemilihan Umum (KPU) sebagai penyelenggara Pemilu, para calon yang dipilih dalam Pemilu maupun masyarakat sebagai pemilih. Selain itu sebabgaki calon yang dipilih penting untuk memahami posedur dan proses sehingga pelaksanaan dapat dilakukan dengan baik. Serta masyarakat penting juga untuk memahami terkait prosedur atau proses maupun calon yang akan dipilih agar hak masyarakat dalam demokrasi khususnya melalui pemilu dapat tersampaikan dengan baik. Begitu pula apabila terdapat penyimpangan yang dilakukan berbagai pihak dalam proses pra-Pemilu, saat Pemilu maupun pasca Pemilu. Tidak hanya penyimpangan secara kuantitatif tetapi penyimpangan yang bersifat kualitatif pun juga dapat terjadi. Misalnya, kesalahan rekapitulasi penghitungan, sekitar 708 kasus khususnya $\mathrm{C} 1$ tertukar dan kesalahan data yang di input pada Sistem Perhitungan KPU (Aryojati Ardipandanto, 2019). Tetapi di sisi lain KPU dapat meningkatkan partisipasi pemilih (Muhammad Choirullah Pulungan, Mudiyati Rahmatunnisa, Ari Ganjar Herdiansah, 2020). Kedaulatan rakyat ditentukan dalam satu waktu, satu waktu itu pula pembuktian atas jaminan hak-hak rakyat yang berkaitan dengan Pemilu. Sedangkan persoalan kompetisi dalam Pemilu apabila tidak dapat diselesaikan dengan baik maka dapat menimbulkan kekacauan. Serta kurang terjaminnya kepastian hukum pada Pemilu sehingga terjadi penyimpangan dalam Pemilu yang tidak terselesaikan dengan baik.

Konsep Pemilu yang merupakan salah satu ciri adanya sistem demokrasi dan merupakan salah satu unsur prinsip negara hukum yang demokratis. Pemilu adalah wujud demokrasi procedural yang merupakan sebagian aspek demokrasi yang mestinya dilakukan secara demokratis, mekanisme demokrasi bertujuan 
untuk memilih seseorang untuk mewakili rakyat dan memimpin pemerintahan (Nyoman Tia Resita Dewi, 2019). Konsep negara hukum terdapat unsur cheks and balances. Prinsip ini untuk menjamin hak-hak rakyat dalam Pemilu dapat terpenuhi. Cheks and balances dapat dilakukan Mahkamah Konstitusi Republik Indonesia (MKRI) sebagai The Guardian of Constitution. Hal ini karena fungsinya MKRI yang berwenang (salah satunya) penyelesaian sengketa Perselisihan Hasil Pemilihan Umum (PHPU) yang dilaksanakan KPU. Oleh karena itu, persoalan tentang terjaminkannya hak-hak rakyat dalam Pemilu penting untuk dibahas. Hal ini dikerenakan Pemilu tahun 2019 merupakan tahun pertama Pemilu serentak. Hak masyarakat untuk memilih tidak hanya pada calon Presiden dan Wakil Presiden saja tetapi juga terhadap DPR, DPD dan DPRD. Kandidat calon yang dipilih oleh rakyat semakin banyak maka semakin banyak proses yang dilalui untuk penyelenggaraan Pemilu maka semakin banyak potensi penyimpangan terjadi dan semakin kompleks. Permohonan Sengketa hasil Pemilihan Legislatif terdapat 339 permohonan di MKRI (329 permohonan diajukan partai politik atau calon legislative, 10 permohonan diajukan calon DPD, 1 permohonan pemilihan presiden) (Fajar Laksono, 2019). Data terakhir peneliti akses informasi sengketa PHPU terhadap Pemilu serentak 2019 telah diputus MKRI sebanyak 321 putusan (MKRI, 2021). Berdasarkan latar belakang masalah yang dipaparkan di atas timbul persolan penting diteliti bagaimana MKRI dalam mewujudkan Demokrasi Berkeadilan (dibatasi Konsep Pemilu). Oleh karenanya penting mengangkat Persoalan hukum dari latar belakang penelitian yaitu Pertama bagaimana fungsi MKRI sebagai the guardian of constitution dalam system demokrasi di Indonesia, Kedua bagaimana fungsi MKRI penafsir tunggal konstitusi dalam pelaksanaan Pemilu, Ketiga bagimana peran putusan MKRI dalam penegakkan demokrasi (khususnya PHPU). Tujuannya adalah menganalisis dan mensistematisasi peran MKRI terkait dengan the guardian of constitution, penafsir tunggal, penegakkan demokrasi (khususnya PHPU). Harapannya adalah menambah khasanah ilmu hukum dan dapat dijadikan pertimbangan dan rujukan untuk perkembangan kelimuan di bidang hukum ketatanegaraan khususnya khususnya terkait kewenangan MKRI dalam mengawal demokrasi.

\section{Rumusan Masalah}

Berdasarkan latar belakang masalah yang dipaparkan di atas timbul persolan penting diteliti bagaimana MKRI dalam mewujudkan Demokrasi Berkeadilan (dibatasi Konsep Pemilu). Berdasarkan latar belakang masalah yang dipaparkan di atas timbul persolan penting diteliti bagaimana MKRI dalam mewujudkan Demokrasi Berkeadilan (dibatasi Konsep Pemilu).

\section{Tujuan}

Tujuannya adalah menganalisis dan mensistematisasi peran MKRI terkait dengan the guardian of constitution, penafsir tunggal, penegakkan demokrasi (khususnya PHPU). Harapannya adalah menambah khasanah ilmu hukum dan dapat dijadikan pertimbangan dan rujukan untuk perkembangan kelimuan di bidang hukum ketatanegaraan khususnya khususnya terkait kewenangan MKRI dalam mengawal demokrasi.

\section{Metode Penelitian}

Metode Penelitian yang dipakai dalam penelitian untuk menganalisis permasalahan yaitu metode penelitian hukum normative karena mendasarkan aspek normatif yang merupakan salah satu logika keilmuan hukum. Artinya, penggunaan metode normative ini karena menganalisis aspek norma dari suatu system yang dalam system tersebut terdapat peranan lembaga Negara yaitu MKRI yang kemudian dilihat dalam aspek penormaan yang mengandung prinsip demokrasi dalam khususnya adalah terkait hak warga negara dalam Pemilu.

\section{Pendekatan}

Dengan demikian maka pendekatan yang digunakan dalam penelitian ini salah satunya adalah pendekatan peraturan perundang-undangan. Misalnya, Pendekatan peraturan perundangundangan digunakan untuk menganalisis kewenangan lembaga yaitu MKRI, prinsip hak warga Negara, prinsip demokrasi dan Negara hukum, serta ketentuan-ketentuan terkait dengan Pemilu. Sedangkan untuk melihat pelaksanaan dan penegakan dari fungsi MKRI sebagai lembaga Negara yang berkaitan dengan konstitusi yang dalam konstitusi mengatur terkait dengan hak warga Negara yang berhubungan dengan demokrasi yang menekankan pada segi konsep maka penelitian ini juga menggunakan pendekatan konseptual. Pendekatan konseptual ini digunakan untuk menganalisis dengan menggunakan doktrin-doktrin yang terkait dengan Constitutional Court atau lembaga yang diberikan kewenangan dalam hal konstitusi, doktrin yang berkaitan dengan konstitusi, hak warga Negara, Pemilu dan doktrin terkait dengan demokrasi juga Negara hokum. Selain itu untuk menganalisis berkenaan dengan penegakan maka tentunya mengkaji juga produk hokum yang telah dihasilkan oleh MKRI dalam menjaga demokrasi menurut konstitusi itu sendiri sehingga penelitian ini juga menggunakan pendekatan kasus yang menekankan pada logika hukum hakim khususnya penafsiran dalam memutus perkara terkait dengan Pemilu. 
Pendekatan ini menggunakan putusan yang kemudian menganalisis logika dan penafsiran hakim terkait dengan Perselisihan Hasil Pemilu. Jadi, dalam penelitian ini setidaknya menggunakan beberapa pendekatan dalam metode normatifnya yaitu pendekatan perundang-undangan, pendekatan konseptual, pendekatan kasus (pengkajian putusan).

Dengan demikian, kerangka teori yang digunakan dalam penelitian ini antara lain pertama, kewenangan MKRI yang berkenaan dengan pemilu yaitu terkait dengan kewenangan penyelesaiaan sengketa perselisihan hasil Pemilu yang telah diatur dalam peraturan perundang-undangan yang berlaku. Kedua, fungsi MKRI the guardian of constitusion yaitu sebagai penjaga konstitusi yang tentunya dibatasi yaitu berkenaan dengan hak warga negara, demokrasi, dan Pemilu dan the final interpreter of constitusion yaitu sebagai penafsir final konstitusi yaitu dibatasi terhadap sengketa perselisihan hasil Pemilu yang diwenangkan kepada MKRI yang mana hakim konstitusi dalam proses penyelesaian sengketa tersebut terdapat logika yuridis yang berkaitan dengan penafsiran terhadap konstitusi yaitu UUDNRI Tahun 1945. Ketiga, Sistem Pemilu yang mmerupakan salah satu pelaksanaan dari prinsip demokrasi yang salah satunya mengandung unsur hak warga negara yang tentunya diatur dalam konstitusi sehingga hak warga negara ini pun dilindungi dalam konstitusi yang tentunya bukan hanya sebatas norma tetapi juga agaimana menegakkan dalam pelaksanaannya (yaitu dengan menjaga hak warga negara dalam proses pemilu yang merupakan salah satu proses pelaksanaan prinsip demokrasi). Keempat, Sistem Demokrasi yang merupakan pelaksanaan dari Pasal 1 ayat (2) UUDNRI Tahun 1945, artinya terdapat jaminan ikut sertanya masyarakat/ warga negara dalam pemerintahan salah satunya yaitu ikut sertanya warga negara dalam proses Pemilu (memilih maupun dipilih). Kelima, Perselisihan Hasil Pemilihan Umum (PHPU), PHPU yang merupakan salah satu kewenangan MKRI sesuai dengan peraturan perundang-undangan yang berlaku (Pasal 24C ayat (1) UUDNRI Tahun 1945 setelah amandemen) yang merupakan kewenanngan yang berkaitan dengan Pemilu yang merupakan salah satu pelaksanaan dari prinsip demokrasi. Keenam, The Guardian of Constitution, merupakan fungsi MKRI sebagai penjaga konstitusi yaitu memiliki kewenangan pengujian UU terhadap UUDNRI Tahun 1945 dalam penelitian ini dibatasi pada hal demokrasi khususnya Pemilu. Ketujuh, Penafsiran Konstitusi, yang merupakan alat untuk hakim memberikan definisi atau pengertian bagi konstitusi untuk menyelesaikan sengketa yang sedang ditangani hakim dalam penelitian ini dibatasi pada PHPU. Kedelapan, Putusan MKRI, merupakan putusan yang dikeluarkan hakim MKRI terhadap sengketa yang sedang ditangani hakim MKRI khususnya (dalam penelitian ini) terhadap PHPU. Putasan MKRI ini bersifat final. Artinya berlaku dan memiliki kekuatan hukum tetap karena tidak ada upaya lanjutan terhadap putusan yang telah dikeluarkan oleh hakim MKRI. Kesembilan, Check and Balances merupakan fungsi mengawasi sehingga bagaimana MKRI mewujudkan fungsi tersebut yang berdasar prinsip demokrasi. Prinsip Check and Balances yang merupakan konsekuensi adanya prinsip negara hukum bahwa perbuatan pemerintah yang sudah diatur oleh hukum dalam pelaksanaannya perlu pengawasan agar tidak keluar dari prinsip negara hukum.

Penelitian berjudul Fungsi MK dalam Sistem Pemilihan Umum dalam Rangka Penegakkan Negara Hukum dan Demokrasi, menggunakan metode normatif dengan berbagai pendekatan dan dianalisis secara kualitatif terkait dengan bagaimana fungsi MKRI sebagai the guardian of constitution dalam system demokrasi di Indonesia, Kedua bagaimana fungsi MKRI penafsir tunggal konstitusi dalam pelaksanaan Pemilu, Ketiga bagimana peran putusan MKRI dalam penegakkan demokrasi (khususnya PHPU). Metode penelitian yang digunakan dalam penelitian ini adalah metode yuridis normatif. Penelitian hukum normatif yang peneliti lakukan mengandung pengetian bahwa penelitian dilakukan dengan cara meneliti bahan pustaka atau data sekunder. Artinya, penelitian ini menganalisis persoalan dengan berfokus pada aspek hukum merupakan sesuatu yang ada (yang tertulis) dalam peraturan. Peraturan perundang-undangan yang dipakai untuk menganalisis salah satunya UUDNRI Tahun 1945, terkait fungsi MKRI dalam PHPU selain itu termasuk peraturan perundang-undangan diantaranya terkait dengan MKRI maupun Pemilu. Peneliti dalam melakukan analisis tentunya menggunakan beberapa pendekatan. Salah satunya menggunakan pendekatan peraturan perundangundangan yang mana menganalisis persoalan menggunakan peraturan perundang-undangan yang relevan dengan isu hukum yang diangkat peneliti. Artinya, menelaah persoalan dengan kesesuaian peraturan perundang-undangan terkait yang sedang berlaku yaitu kesesuaian antar ketentuan yang satu dengan ketentuan yang lainnya. Selain menggunakan pendekatan peraturan perundang-undangan juga pendekatan konseptual atau doktrin. Peneliti ketika menggunakan pendekatan konseptual atau doktrin, peneliti merujuk pada prinsip-prinsip hukum yang ditemukan dalam doktrin hukum yang terkait dengan bidang yang diteliti. Hal ini juga dipakai peneliti memahami maksud isi ketentuan dalam peraturan perundang-undangan yang digunakan untuk menganalisis persoalan. Misalnya, UUDNRI Tahun 1945, Undang-undang Republik Indonesia Nomor 7 Tahun 2017 tentang Pemilihan Umum, Peraturan 
Komisi Pemilihan Umum Republik Indonesia Nomor 7 Tahun 2019, Deklarasi Universal Hak Asasi Manusia (DUHAM). Pendekatan konseptual atau doktrin dipakai untuk memahami prinsip hukum yang ada yang kemudian untuk menganalisis persoalan yang penulis angkat terkait dengan kewenangan MKRI, Pemilu, Prinsip demokrasi dan negara hukum. Hal ini dengan menelaah dari buku, jurnal maupun pustaka lainnya yang berkaitan. Pendekatan yang peneliti fokuskan dalam hal ini adalah berkenaan dengan prinsip demokrasi yang berkaitan dengan pemilu merupakan salah satu aspek dari demokrasi, selain itu terkait negara hukum yang menfokuskan suatu perbuatan pemerintah itu harus memiliki dasar legalitas sehingga organ yang menjalankan kewenangan memiliki dasar legalitasnya (hal ini peneliti gunakan untuk menganalisis kewenangan organ terkait seperti MKRI dan penyelenggara pemilu). Selain itu menggunakan pendekatan kasus (pengkajian putusan) untuk menganalisis argumen hakim MKRI dalam menangani PHPU. Misalnya terkait Putusan MKRI Nomor 14/PUU-XI/2013 pengujian Pasal 3 ayat (5), Pasal 12 ayat (1), Pasal 12 ayat (2), dan Pasal 112 Undang-undang Nomor 42 Tahun 2008 tentang Pemilihan Umum Presiden dan Wakil Presiden kemudian menjadi konsekuensi yuridis dilaksanakan Pemilu secara serentak.

\section{Metode Pengumpulan Data}

Penelitian ini dilakukan dengan cara meneliti bahan pustaka melalui studi kepustakaan dengan mengambil bahan melalui buku-buku, jurnal-jurnal, dan lainnya yang berkaitan dengan persoalan yang peneliti angkat yang merupakan bahan hukum primer dan bahan hukum sekunder. Persoalan yang diangkat dalam penelitian ini dianalisis dengan metode kualitatif dengan menganalisis yaitu fungsi dari MKRI, system pemilu dan system demokrasi yang kemudian disampaikan secara diskripsi analisis dengan metode tertentu (yang sudah dibahas dalam kalimat sebelumnya).

\section{Teknik Analisa Data}

Setelah menganalisis persoalan dengan doktrin dan peraturan perundang-undangan dengan metode yang telah disebutkan sebelumnya dengan analisis kualitatif kemudian diambil hasil. Analisis ini dilakukan dengan melakukan interpretasi terhadap fenomena - fenomena yang ada. Proses tersebut untuk menambah atau memperbanyak analisis. Hasil analisis disusun sistematis sehingga dapat ditarik kesimpulan. Penelitian dilakukan selama 6 (enam) bulan atau satu semester mulai November 2020 sampai dengan April 2021.

\section{PEMBAHASAN (font 12pt, bold, capital)}

Pemerintah idealnya merupakan pemerintah yang demokratis berdasarkan konstitusi merupakan ciri negara hukum yang modern (Nabitatus Sa'adah, 2019). Negara memiliki prinsip-prinsip ketatanegaraan yang diatur dalam konstitusi, pada negara Indonesia maka prinsip-prinsip ketatanegaraan diatur dalam UUDNRI Tahun 1945. Pasal 1 ayat (2) UUDNRI Tahun 1945 mengatur bahwa Kedaulatan berada di tangan rakyat dan dilaksanakan menutut UUD. Pada ketentuan ini terdapat prinsip-prinsip atau nilai-nilai demokrasi. Demokrasi yang ada di Indonesia didampingi dengan prinsip-prinsip negara hukum. Hal ini dapat dilihat setelah frasa kedaulatan rakyat terdapat frasa dilaksanakan menurut UUD. Prinsip negara hukum diatur dalam ketentuan Pasal 1 ayat (3) UUDNRI Tahun 1945 bahwa Negara Indonesia adalah negara hukum. Oleh karena itu kedaulatan rakyat yang merupakan demokrasi itu dibatasi dengan negara hukum.

Salah satu perwujudan adanya prinsip-prinsip kedaulatan rakyat/ demokrasi yaitu dengan dilaksanakan salah satunya adalah Pemilu. Pemilu adalah suatu syarat yang mutlak bagi negara demokrasi untuk melaksanakan kedaulatan rakyat (Titik Triwulan Tutik, 2011). Pemilihan wakil-wakil rakyat dalam sistem ketatanegaraan di Indonesia menggunakan sistem Pemilu. Hal ini diatur dalam konstitusi seperti dalam Pasal 6A UUDNRI Tahun 1945. Misalnya, hal ini dalam Pemilihan Umum Presiden, Wakil Presiden, DPR, DPD, dan DPRD. Pemilu selain sebagai pencerminan negara demokrasi, Pemilu juga merupakan jaminan terhadap hak-hak warga negara yang diatur dalam konstitusi. Hal ini berarti melaksanakan proses Pemilu adalah merupakan perwujudan penjaminan hak-hak warga negara.

Adanya perbedaan pelaksanaan Pemilu pada Tahun 2019 adalah dilakukannya Pemilu secara serentak. Hal ini berarti Pemilu terhadap Presiden, Wakil Presiden DPR, DPD, dan DPRD dilakukan secara bersamaan dalam satu waktu yang sama. Selain KPU harus bekerja lebih ekstra dari pada Pemilu di tahun sebelumnya. Hal ini tentu saja menambah kompleksnya pelaksanaan proses Pemilu dan dapat membawa implikasi bahwa akan semakin kompleks persoalan yang timbul dalam proses Pemilu dan tentu saja akan menimbulkan suatu ketidakadilan dalam sistem demokrasi. Karena dalam proses pelaksanaan Pemilu tidak dapat dipungkiri akan timbul suatu penyimpanganp-penyimpangan yang ada pada pra-Pemilu, saat Pemilu maupun pada pasca-Pemilu. Penyimpangan-penyimpangan dalam hal kuantitatif maupun penyimpangan-penyimpangan secara kualitatif. Oleh karena itu perlu adanya cheks and balances yang dilakukan oleh lembaga yang di 
luar penyelenggara proses Pemilu. Checks and balances pada cabang kekuasaan dapat mengawasi dan mengimbangi cabang kekuasaan lainnya intinya tidak ada cabang supreme (Suroso, 2018). Antar cabang kekuasaan yaitu lembaga negara yang sederajat saling mengendalikan (Ivana Eka Kusuma Wardani, 2019). MK hadir untuk menjamin constitutional democracy agar terwujud cheks and balances antara cabang kekuasaan (A Ahsin Thohari. 2009).

Selain itu, Demokrasi didasari oleh beberapa nilai diantaranya adalah menyelesaikan perselisihan dengan damai dan secara lembaga (institutionalized peacefull settlement of conflict) (Mayo, 1960). Di Indonesia sudah memiliki lembaga yang diberikan kewenangan untuk menyelesaiakkan perselisihan. Hal ini termasuk juga dalam hal penyelesaian PHPU yang dilakukan oleh MKRI. MKRI diberikan kewenangan untuk menyelesaikan sengketa perselisihan hasil Pemilu. Walupun MKRI merupakan badan atau lembaga yang menjalankan fungsinya sebagai yudikatif tetapi terdapat beberapa keterkaitan. MKRI merupakan The Guardian of Constitution sehingga MKRI berwenang menyelesaian perkara yang berkaitan dengan kerugian konstitusional atau inkonstitusional atau ketidaksesuaian dengan konstitusi. Sedangkan Pemilu merupakan salah satu hak yang dilindungi oleh konstitusi. Paling penting adalah MKRI memang diberikan kewenangannya oleh konstitusi untuk (salah satunya) adalah menangani sengketa Pemilu. Hal ini diatur dalam Pasal 24C ayat (1) UUDNRI Tahun 1945 dimana tugas dan wewenangnya diantaranya yaitu memutus perselisihan tentang hasil Pemilu.

Inilah merupakan eksistensi MKRI dalam menegakkan konstitusi salah satunya mewujudkan demokrasi yang berkeadilan. Peranannya dalam menyelesaikan sengketa Pemilihan Umum bertanggung jawab menjaga hak-hak rakyat dalam Pemilu. Hal ini terkait pula dengan tuntutan hakim yang independen menjaga nilai konstitusi. MKRI dalam hal ini berperan penting dalam menjaga kedaulatan rakyat. Hal ini hak-hak rakyat yang merupakan kedaulatan rakyat yang di dalamnya terdapat prinsip demokrasi pada akhirnya juga tergantung pada hakim pada MKRI dalam hal penanganan upaya yang diajukan warga negara sesuai kewenanngannya. Oleh karena itu diperlukan hakim MKRI yang profesional sebagai The Guardian of Constitution menjaga hak rakyat agar terwujud demokrasi yang berkeadilan. Maka penting meneliti fungsi MKRI sebagai the guardian of constitution dalam system demokrasi di Indonesia, fungsi MKRI penafsir tunggal konstitusi dalam pelaksanaan
Pemilu, dan peran putusan MKRI dalam penegakkan demokrasi (khususnya PHPU).

\section{Fungsi MKRI sebagai the guardian of constitution dalam system negara hukum dan demokrasi di Indonesia}

The guardian of constitution terhadap norma konstitusi yang berkaitan dengan negara hukum dan demokrasi. Prinsip Indonesia dengan negara hukum (Pasal 1 ayat (3) UUDNRI Tahun 1945) membawa konsekuensi yuridis penerapan unsur-unsur negara hukum diantaranya pemerintahan berdasarkan hukum. Negara hukum dalam perkembangannya terdapat perubahan tetapi eksistensi pemeritahan menurut hukum masih tetap ada walaupun memiliki frasa yang berbeda. Begitu juga Indonesia sebelum amandemen UUDNRI Tahun 1945 dalam Penjelasannya terdapat kata rechtstaat sedangkan setelah amandemen masuk dalam Pasal 1 ayat (3) UUDNRI Tahun 1945 dengan frasa negara hukum. Hal ini tentu membawa konsekuensi yuridis dalam pelaksanaannya tidak terbatas pada unsur rechtstaat dan dapat saja dilakukan perkembangan disesuaikan dengan karakteristik Indonesia. Misalnya, berdasar rumusan deklarasi Bangkok, menurut Marbun salah satu prinsip negara hukum adanya perlindungan konstitusional (konstitusi selain menjamin hak-hak individu juga prosedur memperolah perlindungan hak yang dijamin) (SF Marbun, 2003). Terdapat prinsip perlindungan konstitusional artinya adanya perlindungan yang dijamin oleh konstitusi. Sedangkan konstitusi memiliki fungsi salah satunya yaitu adanya pembatasan kekuasaan dan pengawasan terhadap kekuasaan (Dahlan Thaib, Jazim Hamidi, Ni'matul Huda, 2011). Konstitusi sendiri adalah wujud konstitusionalisme yaitu pembatasan kekuasaan akibat penyalahgunaan kekuasaan (Jenedjri M Gaffar, 2013). Dengan demikian prinsip dari penjaminan pemerintahan dilaksanakan menurut hukum masih ada. Hal ini dapat ditegaskan dengan pengertian konstitusi yang merupakan kumpulan peraturan mengatur, membentuk atau memerintah negara (Marwan Mas. 2018). Salah satu unsur negara adalah pemerintah (a government). Artinya konstitusi memiliki peran untuk peraturan mengatur, membentuk atau memerintah pemerintah sehingga hal ini juga tidak dapat epas dari prinsip negara hukum. Perkembangan negara hukum di Indonesia juga disampaikan Mahfud bahawa Pasal 1 ayat (3) mengandunng konsep prismatik bahkan menurut Philipus M Hadjon memiliki karakteristik sendiri dengan ciri khas Pancasila (Yuslim, 2015). Terdapat hubungan yang jelas antara negara hukum dan demokrasi. Prinsip kedaulatan rakyat yang merupakan salah satu wujud demokrasi yang di Indonesia dilaksanakan menurut UUD artinya pemerintahan atas kedaulatan rakyat itu pun 
pelaksanaannya harus sesuai dengan hukum yang berlaku nah disinilah kemudian keterkaitan dengan negara hukum. Begitu juga dalam negara hukum yang mana pemerintah harus berdasarkan hukum sedangkan standar legalitas hukum itu dibentuk oleh pemerintah sehingga perlu adanya pengawasan dari rakyat terhadap jaminan pemerintahan yang berdasar pada aturan dasar yaitu konstitusi dan penjaminan terhadap hak-hak rakyat itu sehingga diperlukan partisipasi dari rakyat inilah keterkaitan negara hukum dan demokrasi. Partisipasi rakyat dalam pemerintahan dapat diwujudkan aktif dalam pengawasan atau berhimpun dalam partai politik (Nia Kania Winayati, 2011). Terhadap negara hukum diperlukan adanya fungsi pengawasan sebagai implementasi dari fungsi konstitusi dan terhadap HAM yang merupakan salah satu muatan konstitusi yang dijamin oleh konstitusi. Demokrasi merupakan cara yang paling aman untuk mempertahankan kontrol atas negara hukum (Franz Magnis Suseno, 1997) Salah satu prinsip demokrasi terdapat perwakilan politik dipilih melalui Pemilu dan Pengawasan serta kontrol pemerintahan (JBJM. Ten Berge, 1996).

Demokrasi merupakan pemerintahan dari untuk oleh rakyat (Dwi Zubaidah dan Munadi, 2020). Artinya, demokrasi berprinsip pada kedaulatan rakyat. Intinya demokrasi merupakan keikutsertaan rakyat maupun kesepakatan bersama atau konsesus mencapai tujuan bersama (Sigit Pandu Wicaksono dan Arief Hidayat, 2013). Hal ini ditegaskan pada Pasal 1 ayat (2) UUDNRI Tahun 1945 yang kemudian pelaksanaannya sesuai dengan UUD. Demokrasi konteks pasal ini mengandung duamakna demokrasi ditangan rakyat dan demokrasi dilimpahkan dalam UUD dapat diartikan demokrasi di tangan rakyat dan pelaksanaanya oleh lembaga dibatasi UUD sehingga demokrasi berdasar atas hukum (Harjono, 2010). Demokrasi terkait legalitas pemerintah atau pemerintahan yang sah yang diakui rakyat (Moh. Mahfud. MD, 1999). Pemerintah bertanggungjawab kepada rakyat atas tindakannya (David Bentham dan Kevin Boyle, 2000). Perkembangannya kemudian dilakukan dengan perwakilan. Perwakilan ini merupakan wujud dari peran serta masyarakat yang dipilih dengan melalui Pemilu yang merupakan salah satu perwujudan dari prinsip demokrasi. Hal ini dapat disebut sebagai demokrasi sebagai pemerintahan perwakilan rakyat yang representatif karena tidak dimungkinkan pemerintahan dijalankan oleh rakyat secara langsung karena urusan pemerintahan yang semakin kompleks, luas daerah dan banyaknya masyarakat (Soehino, 2000). Untuk mewujudkannya perwakilan maka dilakukan pemilihan perwakilan dengan cara diadakannya Pemilu secara demokratis, maksudnya adalah dengan melibatkan rakyat untuk ikut berpartisipasi dalam pemerintahan sesuai Pasal 1 ayat (2) UUDNRI Tahun 1945 menempatkan kedaulatan ada pada tangan rakyat yang pelaksanaannya sesuai dengan UUD maka Pemilu yang dilaksanakan semestinya berdasar pada peraturan perundang-undangan yang telah berlaku. Sedangkan untuk memastikan bahwa penerapan negara hukum dan demokrasi melalui Pemilu itu sesuai dengan hukum maka perlu adanya pengawasan. Pengawasan ini dapat dilakukan oleh rakyat jika terdapat ketidaksesuaian maka ada suatu upaya yang dapat ditempuh salah satunya melalui permohonan kepada MKRI. Upaya yang dilakukan rakyat atas keberatan pelaksanaan fungsi pemerintah ini juga ditegaskan dalam prinsip negara hukum maupun dalam prinsip demokrasi, dalam prinsip negara hukum terdapat unsur peradilan administrasi dan dalam prinsip negara demokrasi rakyat diberi kemungkinan untuk mengajukan keberatan (Benny Bambang Irawan, 2007 dan JBJM Ten Berg, 1996). Hal ini sesuai maksud dibentuk MK memperkuat negara hukum demokrasi serta perlindungan HAM $(\mathrm{H}$ Erli Salia, 2017).

Peran atau hak masyarakat dalam kegiatan atau pelaksanaan pemerintahan yang merupakan perwujudan dari prinsip negara hukum dan demokrasi tertuang dalam konstitusi (UUDNRI Tahun 1945). Salah satunya dengan Pasal 28D ayat (3) UUDNRI Tahun 1945 untuk kesempatan yang sama dalam pemerintahan yang kemudian diperkuat dengan Pasal 43 Undang-undang Nomor 39 Tahun 1999 tentang Hak Asasi Manusia yang mana bagi warga negara memiliki hak dipilih dan memilih dalam Pemilu berdasarkan persamaan hak melalui pemunutan suara langsung, umum, bebas, rahasia, jujur, adil sesuai peraturan. Serta pela,ksanaan Pemilu yang sesuai dengan peraturan perundang-undangan, artinya telah menerapkan ketentuan Pasal 28D ayat (1) salah satunya terkait dengan kepastian hokum. Selain itu prinsip dan pelaksanaan Pemilu, Pasal 22E ayat (1) sampai dengan ayat (6) UUDNRI Tahun 1945. Hal ini tentunya perlu untuk dituangkan dalam peraturan lebih konkrit salah satunya dengan peraturan turunannya, karena konstitusi sebagai hukum dasar tentu materi muatannya menjadi pedoman atau dasar peraturan di bawahnya dibentuk sehingga peraturan di bawahnya ketika dibentuk tidak keluar dari bingkai materi muatan konstitusi. Misalnya melalui Undangundang Nomor 7 Tahun 2017 tentang Pemilihan Umum kemudian diturunkan kembali dalam Peraturan Komisi Pemilihan Umum Nomor 7 Tahun 2019 tentang Perubahan Ketiga atas Peraturan Komisi Pemilihan Umum Nomor 7 Tahun 2017 tentang Tahapan, Program, dan Jadwal Penyelenggaraan Pemilihan Umum Tahun 2019. Peran masyarakat dalam negara hukum dan demokrasi sesuai dengan pembahasan pada paragraf sebelumnya dapat dilaksanakan dengan antara lain: 
1. Adanya peran rakyat dalam pelaksanaan penjaminan dilaksanakan negara hukum dengan mengawasi tindakan yang telah dilakukan pemerintah tetap pada koridor hukum (peraturan perundang-undangan) yang berlaku. Jika berkaitan dengan sengketa PHPU maka termasuk pengawasan terhadap proses Pemilu.

2. Penjaminan dilaksanakan pemerintahan dengan tidak melanggar HAM salah satunya melalui Pemilu. Yaitu dengan menjamin hak rakyat yang tercantum dalam Pasal 27 ayat (1), Pasal 28D ayat (1) dan ayat (3) UUDNRI Tahun 1945 dikuatkan Pasal 43 Undang-undang Nomor 39 Tahun 1999 tentang Hak Asasi Manusia yang mana rakyat berpeluang terhadap pelaksanaan Pasal 28 UUDNRI Tahun 1945 sehingga rakyat tidak dirugikan dalam pelaksannannya serta terwujudnya prinsip dan pelaksanaan Pemilu, Pasal 22E ayat (1) sampai dengan ayat (6) UUDNRI Tahun 1945.

3. Dalam pemilu sebagai pemilih yang memiliki hak atas suara atau pendapatnya terhadap pilihan yang akan dipilih. Tentunya hal ini berkaitan dengan penentuan daftar pemilih yang akan memilih dalam Pemilu.

4. Dalam Pemilu sebagai yang dipilih sebagai perwujudan perwakilan rakyat dalam prinsip demokrasi. Perwakilan rakyat ini kemudian menduduki di pemerintahan untuk menjalankan fungsi pemerintahan yang diharapkan membawa aspirasi masyarakat dan mendasarkan itu untuk melaksanakan fungsi pemerintahan.

5. Melakukan keberatan dengan upaya salah satunya melalui MKRI terhadap sengketa PHPU.

Adanya pengawasan yang dilakukan oleh masyarakat dan ketika terdapat dugaan penyimpangan maka ada upaya salah satunya terkait sengketa PHPU yang diwenangkan kepada MKRI. Meskipun terdapat prosedur Pemilu dan tersedianya mekanisme penyelesaian masalah maka telah terbangun kerangka keadilan pemilu walaupun belum tentu Pemilu berjalan secara adil (Khairul Fahmi, Feri Amsari, Busyra Azheri, Muhammad Ichsan Kabullah, 2020). Fungsi hakim MK sebagai the guardian of constitution ditujukkan pada sikap saat proses penyelesaian sengketa PHPU. Berdasarkan Pasal 24C UUDNRI Tahun 1945, MKRI memiliki kewenangan terhadap sengketa PHPU. Fungsi the guardian of constitution dapat dijelaskan yaitu ketika MKRI menangani sengketa PHPU maka MKRI menjalankan beberapa amanat dalam konstitusi yaitu UUDNRI Tahun 1945 dan menjaga amanat itu agar tidak disimpangi.
Pertama, ketika MKRI menjalankan kewenangannya sesuai dengan Pasal 24C UUDNRI Tahun 1945 salah satunya menyelesaikan sengketa PHPU. MKRI menjalankan fungsi Pasal 24C UUDNRI Tahun 1945 artinya sesuai kewenangannya ketika menerima sengketa PHPU maka berdasarkan kewenangan itu MKRI menyelesaikannya artinya menjaga terlaksananya Pasal 24C UUDNRI Tahun 1945 sesuai materi muatannya dan tidak disimpangi khususnya terkait menangani sengketa PHPU. Dengan MKRI menjalankan fungsi penyelesaian sengketa PHPU sesuai dengan Pasal 24C UUDNRI Tahun 1945 dan peraturan termasuk peraturan di bawahnya yang taat konstitusi dan menjaga dirinya dari penyimpangan secara tidak langsung MKRI telah menjaga marwah konstitusi untuk dilaksanakan sebagaimana mestinya. MKRI melaksanakan tugas dan fungsinya sesuai dengan amanat konstitusi dan tentunya peraturan perundang-undangan yang berlaku.

Kedua, ketika MKRI menjalankan kewenangannya menyelesaikan sengketa PHPU terkait materi muatan Pasal 28D ayat (1) dan ayat (3) UUDNRI Tahun 1945 dikuatkan Pasal 43 Undangundang Nomor 39 Tahun 1999 tentang Hak Asasi Manusia terutama serta prinsip dan pelaksanaan Pemilu, Pasal 22E ayat (1) sampai dengan ayat (6) UUDNRI Tahun 1945. Terhadap sengketa PHPU merupakan konsekuensi terhadap pelaksanaan Pasal 28 UUDNRI Tahun 1945 dan Pasal 22E ayat (1) sampai dengan ayat (6) UUDNRI Tahun 1945 yang mengalami kendala, sehingga kendala itu mestinya diselesaikan agar tidak terjadi kerugian atau ketiadaan hak yang menjadi muatan Pasal 28D ayat (1) dan ayat (3) UUDNRI Tahun 1945 dikuatkan Pasal 43 Undang-undang Nomor 39 Tahun 1999 tentang Hak Asasi Manusia dan Pasal 22E ayat (1) sampai dengan ayat (6) UUDNRI Tahun 1945. Maksudnya MKRI menyelesaikan sengketa PHPU artinya dalam putusannya meluruskan bagaimana semestinya pelaksanaan Pasal 28D ayat (1) dan ayat (3) UUDNRI Tahun 1945 dikuatkan Pasal 43 Undang-undang Nomor 39 Tahun 1999 tentang Hak Asasi Manusia dan Pasal 22E ayat (1) sampai dengan ayat (6) UUDNRI Tahun 1945yang secara lebih rinci ditur lebih lanjut pada peraturan perundang-undangan pada tingkat bawahnya. Maka secara MKRI melalui putusannya menjaga eksistensi keharusan norma itu berlaku khususnya Pasal 28D ayat (1) dan ayat (3) UUDNRI Tahun 1945 dikuatkan Pasal 43 Undangundang Nomor 39 Tahun 1999 tentang Hak Asasi Manusia dan Pasal 22E ayat (1) sampai dengan ayat (6) UUDNRI Tahun 1945. Hak tersebut berkaitan dengan rakyat sebagai pemilih maupun sebagai yang dipilih. Artinya MKRI dengan melalui putusannya menjaga agar pelaksanaan Pasal 28D ayat (1) dan ayat (3) UUDNRI Tahun 1945 dikuatkan Pasal 43 
Undang-undang Nomor 39 Tahun 1999 tentang Hak Asasi Manusia dan Pasal 22E ayat (1) sampai dengan ayat (6) UUDNRI Tahun 1945 dapat berjalan sesuai dengan tujuan materi muatan Pasal 28D ayat (1) dan ayat (3) UUDNRI Tahun 1945 dikuatkan Pasal 43 Undang-undang Nomor 39 Tahun 1999 tentang Hak Asasi Manusia dibentuk. Secara tidak langsung, menjamin hak rakyat sebagai pemilih maupun sebagai yang dipilih tidak dilanggar. Hal ini juga secara tidak langsung MKRI melaksanakan fungsinya sebagai pelindung HAM (the protector of human right) dan pelindung demokrasi (the protector of democracy). The protector of human right ketika berkaitan dengan hak warga negara sebagai pemilih maupun dipilih dilanggar, misalnya ketika terjadi perselisihan dalam penghitungan atau hak mencalonkan yang dirugikan ketika hakim memutus dengan berkeadilan maka tercerminkan the protector of human right. The protector of democracy terhadap proses Pemilu dapat dijalankan sebagaimana mestinya.

Ketiga, ketika penjatuhan putusan oleh hakim konstitusi sesuai dengan maksud knstitusi artinya adanya upaya warga negara yang tersampaikan, MKRI menjalankan sesuai kewenangannya dalam konstitusi, dan merupakan cerminan pelaksanaan cheks and balances terhadap lembaga penyelenggara Pemilu (yaitu terhadap lembaga penyelenggara Pemilu untuk tetap melaksanakan tugas dan fungsinya sesuai dengan peraturan perundangundangan yang berlaku) sehingga mewujudkan terjaminnya negara hukum sebagai konsekuensi yuridis Pasal 1 ayat (3) UUDNRI Tahun 1945. Hal ini sebagai bentuk upaya rakyat terhadap persoalan atau kerugian atau ketidaksesuaian pelaksanaan pemerintahan sesuai prinsip negara hukum terdapat upaya bagi keberatan yang dirasakan oleh rakyat.

Keempat, sebagai bentuk menjaminnya Pasal 1 ayat (2) UUDNRI Tahun 1945 sebagai upaya penjagaan terhadap Pemilu yang dilaksanakan sesuai dengan hukum yang berlaku merupakan salah satu perwujudan keterwakilan dalam prinsip negara yang demokratis dan menjamin pelaksanaan Pemilu sesuai Pasal 22E UUDNRI Tahun 1945. Hal ini juga secara tidak langsung MKRI melaksanakan fungsinya sebagai pelindung demokrasi (the protector of democracy).

\section{Kedua bagaimana fungsi MKRI penafsir tunggal konstitusi dalam pelaksanaan Pemilu}

Kewenangan MK dalam demokrasi juga terwujud dalam kewenangan MK ketika melaksanakan Pasal 24C UUDNRI Tahun 1945 yaitu berkaitan dengan memutus PHPU. Hakim MK pada saat menyelesaikan sengketa PHPU tentu menggunakan penafsiran untuk memaknai ketentuan dalam peraturan. Penafsiran konstitusi dilakukan ketika ketidak jelasan hukum seperti penafsiara yang diterapkan gdalam bidang hukum lainnya (Muchamad Ali Safaat, Aan Eko Widiarto, Fajar Laksono Suroso, 2017).

Esksistensi pada penafsiran pun juga pernah dilakukan dalam sengketa PHPU. Permohonan sengketa PHPU kepada MKRI merupakan upaya terhadap terjadinya kemungkinan adanya kerugian dalam proses Pemilu.

1. Terhadap Pasal 24C UUDNRI Tahun 1945, MKRI sebagai pelaksana kekuasaan kehakiman yang berwenang mengadili salah satunya yaitu memutus PHPU. MKRI melaksanakan tugas dan fungsinya sesuai dengan kehtentuan ini secara tidak langsung MKRI telah menjaga agar ketentuan konstitusi ini ditegakkan. Hal ini merupakan salah satu upaya yang dapat diajuka warga negara untuk mempertahankan haknya salahsatunya yang kaitan dengan Pemilu. Dengan demikian artinya MKRI ketika tuhgas dan kewenanngan MK ini dijalankan dengan benar maka MKRI telah berupaya mewujudkan demokrasi yang berkeadilan.

2. Terhadap Pasal 28D ayat (1) dan ayat (3) UUDNRI Tahun 1945 dikuatkan Pasal 43 Undang-undang Nomor 39 Tahun 1999 tentang Hak Asasi Manusia yaitu,

a. Terdapat Pengakuan, jaminan, perlindungan, dan kepastian hukum yang adil dan perlakuan yang sama di hadapan hokum merupakan hak setiap orang yang juga termasuk orang yang ingin memilih dan dipilih dalam suatu Pemilu serta upaya untuk mendapatkan hak tersebut. Adanya upaya yang dapat dilakukan oleh masyarakat dalam penyelesaian sengketa PHPU merupakan salah satu cara untuk mewujudkan hal ini. Misalnya terkait penghitungan sehingga terang mana semestinya yang terpilih dan siapa yang akhirnya dipilih untuk mengisi jabatan tertentu yang merupakan pilihan warga negara yang berpartisipasi yang memiliki hak suara. Oleh karena itu upaya penyelesaiannya merupakann salah satu cara penegakan HAM dari segi Pemilu yang merupakan salah satu pelaksanaan dari system demokrasi.

b. Adanya hak kesempatan yang sama yang dimiliki oleh warga negara di sebuah pemerintahan. Wujud diterapkannya merupakan salah satu 
prinsip dari demokrasi misalnya keikutsertaan dalam Pemilu yang merupakan salah satu upaya partisipasi masyarakat/ warga negara dalam pemerintahan. Begitu juga memiliki kesempatan yang sama dalam mengupayakan hak yang telah dirugikan termasuk salah satunya sengketa PHPU. Dan kesempatan yang sama bagi pemilih yang memiliki hak pilih dalam menentukan pilihannya yang akan diikutkan atau mewakilinya dalam system pemerintahan serta kesempatan yang sama bagi yang dipilih untuk mencalonkan atau mengikuti Pemilu sehingga yang terpilih secara adil dapat mewakili warga negara untuk berpartisipasi dalam pemerintahan dengan menduduki beberapa jabatan yang disediakan dalam Pemilu. MKRI ketika mnyelesaiakan sengketa PHPU artinya untuk mempertahankan hak mereka secara adil sehingga tidak dicurangi.

c. Adanya hak dipilih, memilih dalam Pemilu berdasar persamaan hak melalui pemungutan suara yang langsung, umum, bebas, rahasia, jujur, dan adil sesuai dengan ketentuan perundang-undangan merupakkan hak yang dimiliki oleh warga negara. Upaya yang dapat dilakukan warga negara melalui penyelesaian sengketa PHPU yang dilakukan oleh MKRI, artinya MKRI berusaha untuk menjaga agar hak tersebut benar-benar dilaksanakan.

3. Terhadap Pasal 22E ayat (1) sampai dengan ayat (6) UUDNRI Tahun 1945, M MKRI K ketika menjalankan tugas dan fungsinya sebagai lembaga yang berwenanng dalam upaya warga negara terhadap haknya yaitu sengketa PHPU maka MK telah berupaya untuk ketentuan ini diwujudkan.

Salah satunya penanganan terhadap PHPU dilakukan oleh MKRI dengan penafsiran pernah dilakukan dengan penafsiran ekstensif (menilai hasil perolehan suara tapi juga) dengan melebihi batas gramatikal (juga pelanggaran terstruktur, sistematis, massif) terhadap yang dapat mempengaruhi perolehan suara, misalnya (Helmi Kasim, Syukri Asy'ari, Meyrinda R. Hilipito, Rio Tri Juli Putransti, 2012):
1. Putusan MKRI Nomor 41/PHPU.D-VI/2008 dalam Pilkada dengan pemungutan suara dan penghitungan suara ulang.

2. Putusan MKRI Nomor 57/PHPU.D-VI/2008 dengan Pendiskualifikasian Salah Satu Pasangan Calon karena Pelanggaran Administratif dalam Pilkada.

3. Putusan MKRI Nomor 9/PHPU.D-VIII/2010 Putusan sela pemungutan suara ulang dalam Pemilukada.

Penafsiran ini dilakukan karena proses kualitatif dianggap mempengaruhi kuantitatif (hasil perolehan suara) dengan demikian penafsiran yang dilakukan MKRI sebagai penafsir konstitusi dalam rangka demokrasi (Pemilu). Penafsiran hakim konstitusi dalam menanngani sengketa PHPU dapat disebut sebagai penafsir tunggal karena berkaitan dengan pelaksanaan konstitusi yang terkait dengan Pemilu dan hanya MKRI saja yang dapat atau diberikan kewenangan atau dperbolehkan menafsirkan konstitusi.

Penafsiran hakim MKRI juga dilakukan ketika hakim MKRI menyelesaikan Sengketa PHPU terhadap Pemilu yang tersebut sebelumnya yaitu terkait dengan proses sudah tidak diterapkan pada sengketa PHPU terhadap Pemilu yang dilakukan Serentak pada Tahun 2019 MKRI tidak memiliki kewenangan dapat diketahui dalam Putusan MKRI Nomor 01/PHPU-PRES/XVII/2019 tanggal 27 Juni 2019 terhadap pelanggaran TSM (terstuktur, sistematis, masif) yang merupakan pelanggaran administrative jika tidak pernah diajukan sebelum PHPU yang juga diikuti pada Putusan MKRI Nomor 33-13-02/PHPU.DPR-DPRD/XVII/2019 yang dilanjutkan argument bahwa hal tersebut merupakan kewenangan Lembaga Penyelenggara Pemilu (Undang-Undang Nomor 7 Tahun 2017 tentang Pemilihan Umum). Selain itu kewenangan yang demikian itu dianggap pelampauan terhadap kewenangan MKRI walau maksud MKRI untuk demokrasi substansial (M Mahrus Ali, Irfan Nur Rachman, Winda Wijayanti, Rio Tri Juli Putranto, Titis Anindyajati, Putria Gusti Asih, 2012).

\section{Ketiga Peran Putusan MKRI Dalam Penegakkan Demokrasi (khususnya PHPU)}

Putusan MKRI bersifat final and binding karena didasarkan pada Pasal 10 ayat (1) Undangundang Nomor 24 Tahun 2003 tentang Mahkamah Konstitusi diubah dengan Undang-undang Nomor 8 Tahun 2011 tentang Perubahan Atas Undang-undang Nomor 24 Tahun 2003 tentang Mahkamah Konstitusi memiliki sifat final salah satunya terkait memutus PHPU dengan frasa tidak ada upaya hukum yang juga dapat diahrtikan bahwa putusan yang dikeluarkan 
MKRI dalam rangka memutus PHPU memiliki kekuatan hukum mengikat. Hal ini memiliki pengertian bahwa adanya penguatan fungsi MKRI sebagai the guardian of constitutions khususnya the protector of human right yang merupakan perwujudan HAM salah satunya terkait dengan hak pilih dan dipilih, hak perlakuan sama dan kesempatan sama di depan hukum dan the protector of democracy dalam hal menjamin pelaksanaan Pemilu khususnya terkait hasil pemilu agar terjadi sebagaimana mestinya tidak menciderai demokrasi karena Pemilu itu sendiri merupakan salah satu wujud dari eksistensi demokrasi yang merupakan perwujudan kedaulatan rakyat yang dijaminkan konstitusi UUDNRI Tahun 1945

\section{PENUTUP}

\section{Kesimpulan}

Kesimpulan paparan pembahasan di atas adalah perlu adanya Mahkamah Konstitusi sebagai unsur prinsip cheks and balances. Selain itu hakim Mahkamah Konstitusi berkewajiban melaksanakan kewenangannya dengan profesional dan penuh tanggung jawab. Pemilihan Umum pada dasarnya adalah wujud dari hak-hak rakyat yang dilindungi oleh konstitusi. Mahkamah Konstitusi apabila terdapat sengketa pada Pemilihan Umum dan dapat menjaga integritasnya maka akan mewujudkan demokrasi yang berkeadilan. Mahkamah Konstitusi betul-betul menjaga marwah konstitusi dan telah menkjalankan fungsinya sebagai The Guardian of Constitution untuk mewujudkan Demokrasi Berkeadilan. Fungsi the guardian of constitution dapat dijelaskan yaitu ketika MKRI menangani sengketa PHPU maka MKRI menjalankan beberapa amanat dalam konstitusi yaitu UUDNRI Tahun 1945 dan menjaga amanat itu agar tidak disimpangi. Pertama, ketika MKRI menjalankan kewenangannya sesuai dengan Pasal 24C UUDNRI Tahun 1945 salah satunya menyelesaikan sengketa PHPU. Kedua, ketika MKRI menjalankan kewenangannya menyelesaikan sengketa PHPU terkait materi muatan Pasal 28D ayat (1) dan ayat (3) UUDNRI Tahun 1945 dikuatkan Pasal 43 Undang-undang Nomor 39 Tahun 1999 tentang Hak Asasi Manusia terutama serta prinsip dan pelaksanaan Pemilu, Pasal 22E ayat (1) sampai dengan ayat (6) UUDNRI Tahun 1945. Ketiga, ketika penjatuhan putusan oleh hakim konstitusi sesuai dengan maksud knstitusi artinya adanya upaya warga negara yang tersampaikan, MKRI menjalankan sesuai kewenangannya dalam konstitusi, dan merupakan cerminan pelaksanaan cheks and balances terhadap lembaga penyelenggara Pemilu. Keempat, sebagai bentuk menjaminnya Pasal 1 ayat (2) UUDNRI Tahun 1945 sebagai upaya penjagaan terhadap Pemilu yang dilaksanakan sesuai dengan hukum yang berlaku merupakan salah satu perwujudan keterwakilan dalam prinsip negara yang demokratis dan menjamin pelaksanaan Pemilu sesuai Pasal 22E UUDNRI Tahun 1945. Fungsi MKRI dalam sistem pemilu dalam rangka penegakkan demokrasi dan juga negara hukum dapat dilihat dalam proses penanganan sengketa PHPU oleh MKRI. Hakim MKRI yang profesional sebagai the Guardian of Constitution menjaga hak rakyat agar terwujud demokrasi yang berkeadilan. Pertama, dalam fungsi MKRI sebagai the guardian of constitution dalam system demokrasi di Indonesia dengan menangani PHPU sebagaimana mestinya melindungi hak warga negara yang merupakan salah satu HAM. Kedua, fungsi MKRI penafsir tunggal konstitusi ketika melakukan penafsiran pada konstitusi untuk PHPU dan hanya MKRI saja yang memiliki kewenangan untuk itu. Penafsiran ini dilakukan karena proses kualitatif dianggap mempengaruhi kuantitatif (hasil perolehan suara) dengan demikian penafsiran yang dilakukan MKRI sebagai penafsir konstitusi dalam rangka demokrasi (Pemilu). Penafsiran hakim konstitusi dalam menanngani sengketa PHPU dapat disebut sebagai penafsir tunggal karena berkaitan dengan pelaksanaan konstitusi yang terkait dengan Pemilu dan hanya MKRI saja yang dapat atau diberikan kewenangan atau dperbolehkan menafsirkan konstitusi. Penafsiran hakim MKRI juga dilakukan ketika hakim MKRI menyelesaikan Sengketa PHPU terhadap Pemilu yang tersebut sebelumnya yaitu terkait dengan proses sudah tidak diterapkan pada sengketa PHPU terhadap Pemilu yang dilakukan Serentak pada Tahun 2019 MKRI tidak memiliki kewenangan Ketiga, peran putusan MKRI dalam penegakkan bersifat final and binding terhadap PHPU oleh karena harus dilaksanakan. Hal ini juga secara tidak langsung MKRI melaksanakan fungsinya sebagai pelindung demokrasi. 


\section{UCAPAN TERIMA KASIH}

Penulis sampaikan terima kasih kepada para pihak yang turut mendukung dan membantu secara langsung maupun tidak langsung untuk terlaksanakannya penelitian ini.

Buku

\section{DAFTAR PUSTAKA}

Mayo, H.B.(1960). An Introduction to Democratic Theory. New York: Oxford Univercity Press.

Suroso, F.L. (2018). Potret Relasi Mahkamah Konstitusi-Legislator. Yogyakarta: Genta

Titik Triwulan Tutik. (2011). Konstruksi Hukum Tata Negara Indonesia Pasca Amandemen UUD 1945. Jakarta: Kencana.

Moh. Mahfud, MD, (1999). Pergulatan Politik dan Hukum. Yogyakarta: Gama Media. hal. 23.

David Bentham dan Kevin Boyle, (2000). Demokrasi. Yogyakarta: Kanisius. hlm. 55.

SF Marbun, 2003, Pengadilan Administrasi dan Upaya Administrasi di Indonesia. Yogyakarta: Liberty. hal. 7.

Dahlan Thaib, Jazim Hamidi, Ni'matul Huda. (2011). Teori dan Hukum Konstitusi. Jakarta: RajaGrafindo Persada. hal 22-23

Marwan Mas. (2018). Hukum Konstitusi dan Kelembagaan Negara. Depok. Rajawali Pers. hal. 11.

Yuslim, (2015). Hukum Acara Peradilan Tata Usaha Negara. Jakarta: Sinar Grafika. hal. 10.

Franz Magnis Suseno, (1997). Mencari Sosok Demokrasi, Sebuah Telaah Filosofi. Jakarta: Gramedia. hal. 58

JBJM. Ten Berge, (1996). Besturen door de Overheid. WEJ Tjeenk Willink, Deventer, 1996, hal. 34-38.

Soehino, 2000. Ilmu Negara. Yogyakarta : Liberty. hal. 243.

Jimly Asshiddiqie, (2015). Konstitusi Bernegara: Praksis Kenegaraan Bermartabat dan Demokratis. Malang: Setara Press. hal. 186.

Nyoman Tia Resita Dewi, (2019). Pengaruh Pemilu Serentak di Indonesia, Seminar Nasional I Hukum dan Kewarganegaraan. Singaraja Universitas Pendidikan Ganesha. tanggal 05 Oktober 2019, hal 1-2

\section{Jurnal}

A Ahsin Thohari. 2009. Mahkamah Konstitusi dan Pengokohan Demokrasi Konstitusional di Indonesia. Jurnal Legislasi Indonesia Volume 6 Nomor 3 September 2009. hal. 102.

Apolonaris Gai dan Frans Bapa Tokan, 2020. Pemilu Serentak: Analisa Dampak Penyelenggaraan Pemilu Setentak Dalam Meningkatkan Kualitas Demokrasi di Indonesia: Studi Kasus Penyelenggaraan Pemilu di Kota Kupang -
Provinsi Nusa Tenggara Timur Tahun 2019. Warta Gorvernare: Jurnal Ilmu Pemerintahan, Volume 1 Nomor 2, Januari-Juni 2020. hal. 112-113.

Aryojati Ardipandanto. 2019. Permasalahan Penyelenggaraan Pemilu Serentak Tahun 2019. Bidang Pemerintahan Dalam Negeri Info Singkat : Kajian Singkat Terhadap Isu Aktual dan Strategis. Volume XI Nomor 11/I/Puslit/Juni/2019.Pusat Penelitian Badan Keahlian DPR RI Gd. Nusantara I Lt 2. Jakarta Pusat. hal 27.

Benny Bambang Irawan. (2007). Perkembangan Demokrasi di Negara Indonesia. Hukum dan Dinamika Masyarakat Volume 5 Nomor 1 Oktober. hal. 56-57

Dwi Zubaidah dan Munadi, 2020. Peran Komisi Pemilihan Umum Kabupaten Wonosobo dalam Pendidikan Politik untuk Masyarakat pada Pemilu Serentak 2019. Unnes Political Science Journal 4 (2) (2020). hal. 64-68

Harjono. 2010. Hukum, Demokrasi, dan Mahkamah Konstitusi. INOVATIF. Volume 2 Nomor 3. 2010. hal. 10-11

H Erli Salia. 2017. Peran Mahkamah Konstitusi dalam Mewujudkan Negara Hukum yang Demokratis. DiH Jurnal Ilmu Hukum Volume 13 Nomor 25. hal. 37.

Ivana Eka Kusuma Wardani, 2019. Peran Mahkamah Konstitusi dalam Mengawal Prinsip Checks and Balances terhadap Dewan Perwakilan Daerah di Indonesia. Volksgeist, Volume 2 Nomor 2 Desember 2019. hal. 243

Jenedjri M Gaffar, 2013, Peran Putusan Mahkamah Konstitusi dalam Perlindungan Hak Asasi Manusia terkait Penyelenggaraan Pemilu. Jurnal Konstitusi. Volume 10 Nomor 1 Maret 2013. hal. 3.

Helmi Kasim, Syukri Asy'ari, Meyrinda R. Hilipito, Rio Tri Juli Putransti. 2012. Kompatibilitas Metode Pembuktian dan Penafsiran Hakim Konstitusi dalam Putusan Pemilukada: The Compatibility of Method of Evidence Examination and the Justices Interpretation in the Decision of Local Election Dispute. Jurnal Konstitusi Volume 9 Nomor 4 Desember 2012. hal 714-739.

Khairul Fahmi, Feri Amsari, Busyra Azheri, Muhammad Ichsan Kabullah, 2020, Sistem Keadilan Pemilu dalam Penanganan Pelanggaran dan Sengketa Proses Pemilu Serentak 2019 di Sumatera Barat: Electoral Justice System in Handling 2019 Concurrent Election Violations and Disputes in West Sumatra. Jurnal Konstitusi . Volume 17 Noor 2 Maret 2020. hal. 1-26. 
Kornelius Benuf, 2019, Harmonisasi Hukum: Pemilu Serentak dan Ketenagakerjaan, Analisis Yuridis uterhadap Kematian KPPS Tahun 2019, Jurnal Gema Keadilan, Volume 6, Edisi II, Agustus 2019, hal 198.

M Mahrus Ali, Irfan Nur Rachman, Winda Wijayanti, Rio Tri Juli Putranto, Titis Anindyajati, Putria Gusti Asih, 2012. Tafsir Konstitusional Pelanggaran Pemilukada yang Bersifat Sistematis, Terstruktur, Masif. Jurnal Konstitusi Volume 9 Nomor 1 Maret 2012. Hal. 194.

Moch. Nurhasim, 2019. Paradoks Pemilu Serentak 2019: Memperkokoh Multipartai Ekstrim di Indonesia: The Paradox of Simultaneous Elections In 2019: Strengthening Extreme Multiparty In Indonesia. Jurnal Penelitian Politik. Volume 16 Nomor 2 Desember 2019 hal. 125-136.

Muchamad Ali Safaat, Aan Eko Widiarto, Fajar Laksono Suroso, 2017. Pola Penafsiran Konstitusi dalam Putusam ahkamah Konstituso Periode 2003-2008 dan 2009-2013: The Pattern of Constitutional Interpretation on The Constitutional Court Decisions in the period 2003-2008 and 2009 - 2013. Jurnal Konstitusi Volume 14 Nomor 2 Juni 2017. hal. 239.

Muhammad Choirullah Pulungan, Mudiyati Rahmatunnisa, Ari Ganjar Herdiansah, 2020. Strategi Komisi Pemilihan Umum Kota Bekasi dalam Meningkatkan Partisipasi Pemilih pada Pemilu Serentak Tahun 2019. POLITEA: Jurnal Politik Islam. Volume 3 Nomor 2 JuliDesember 2020. Hal. 251-271

Nabitatus Sa'adah, 2019. Mahkamah Konstitusi sebagai Pengawal Demokrasi dan Konstitusi Khususnya dalam Menjalankan Constitutional Review. Administrative LA \& Governance Journal, Volume 2 Issue 2, June 2019. hal 236.

Nia Kania Winayati, 2011. Makna Pasal 28 UUD 1945 terhadap Kebebasan Berserikat dalam Konteks Hubungan Industrial. Jurnal Konstitusi Volume 8. Nomor 6. Desember 2011. hal. 971.

Saldi Isra, 2014, Peran Mahkamah Konstitusi dalam Penguatan Hak Asasi Manusia di Indonesia, Jurnal Konstitusi Vol 11 No 3, hal 411-412

Sigit Pandu Wicaksono dan Arief Hidayat. 2013. Peran Mahkamah Konstitusi dalam Mengawal Demokrasi Lokal. Law Reform. Volume 9 Nomor 1 Oktober Tahun 2013. hal. 146-165

\section{Website}

Fajar Laksono, 2019, Jumlah Sengketa Pemilu 2019 di MK bertambah jadi 340 kasus, CNN Indonesia, Sabtu 01 Juni 2019 Pukul 01:33 WIB, halaman situs: https://www.cnnindonesia.com/nasional/2019 0531134239-32-400029/jumlah-sengketapemilu-2019-di-mk-bertambah-jadi-340-kasus akses 17 April 2021 Pukul 07.00 WIB.

MKRI, 2021, Putusan Mahkamah Konstitusii Republik Indonesia, https://www.mkri.id/index.php?page=web.Put usan\&id=33\&kat=1\&cari=\&menu=5\&jnsperk $\underline{\text { ara }=1 \& j e n i s=P H P U}$, akses 17 April 2021 Pukul 07.15 WIB

\section{Produk Hukum}

Undang-Undang Dasar Negara Republik Indonesia Tahun 1945

Undang-undang Republik Indonesia Nomor 7 Tahun 2017 tentang Pemilihan Umum Lembaran Negara Republik Indonesia Tahun 2017 Nomor 182 , Tambahan Lembaran Negara Republik Indonesia Nomor 6109

Peraturan Komisi Pemilihan Umum Republik Indonesia Nomor 7 Tahun 2019 tentang Perubahan Ketiga atas Peraturan Komisi Pemilihan Umum Nomor 7 Tahun 2017 tentang Tahapan, Program, dan Jadwal Penyelenggaraan Pemilihan Umum Tahun 2019. Berita Negara Republik Indonesia Tahun 2019 Nomor 277. (Peraturan Komisi Pemilihan Umum Nomor 7 Tahun 2017 tentang Tahapan, Program, dan Jadwal Penyelenggaraan Pemilihan Umum Tahun 2019 (Berita Negara Republik Indonesia Tahun 2017 Nomor 1225) sebagaimana telah beberapa kali diubah terakhir dengan dengan Peraturan Komisi Pemilihan Umum Nomor 32 Tahun 2018 tentang Perubahan Kedua atas Peraturan Komisi Pemilihan Umum Nomor 7 Tahun 2017 tentang Tahapan, Program, dan Jadwal Penyelenggaraan Pemilihan Umum Tahun 2019 (Berita Negara Republik Indonesia Tahun 2018 Nomor 1306)).

Deklarasi Universal Hak Asasi Manusia (DUHAM) Putusan MKRI Nomor 41/PHPU.D-VI/2008 Putusan MKRI Nomor 57/PHPU.D-VI/2008 Putusan MKRI Nomor 9/PHPU.D-VIII/2010 Putusan MKRI Nomor 01/PHPU-PRES/XVII/2019 Putusan MKRI Nomor 33-13-02/PHPU.DPRDPRD/XVII/2019 